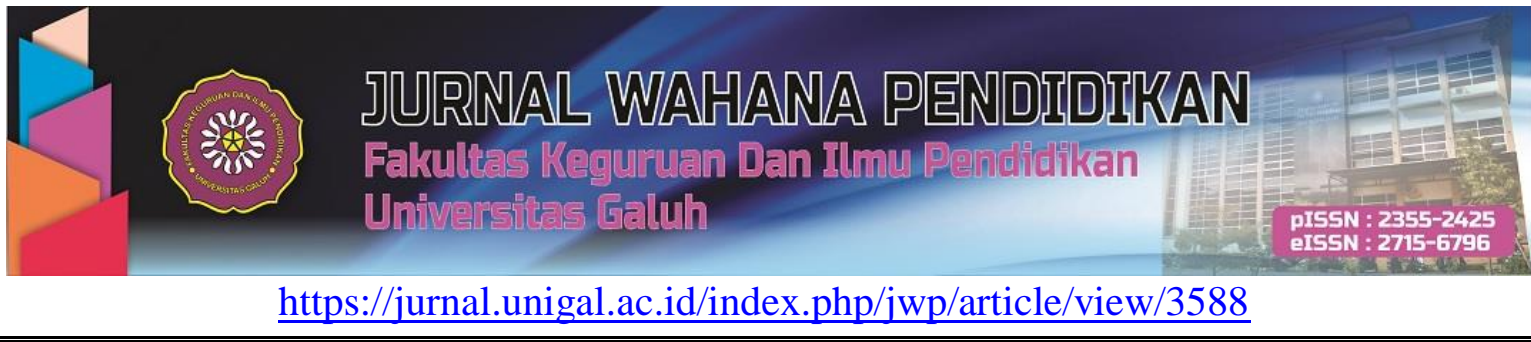

\title{
CITRA PEREMPUAN JAWA DALAM NOVEL GARIS PEREMPUANKARYA SANIE B. KUNCORO DAN IMPLIKASINYA TERHADAP PEMBELAJARAN BAHASA INDONESIA DI SMA
}

\author{
Alfi Nur Afidah ${ }^{1}$, Tri Mulyono ${ }^{2}$, Afsun Aulia Nirmala ${ }^{3}$ \\ ${ }^{1,2,3}$ Program Studi Pendidikan Bahasa Sastra Indonesia, Universitas Pancasakti Tegal \\ Email: alfinurafidah@gmail.com
}

\begin{abstract}
:
The purpose of this study was to describe the image of Javanese women contained in the novel Garis Perempuan by Sanie B. Kuncoro and the implications of learning the image of Javanese women "towards learning Indonesian in" high school. The research method used is a descriptive qualitative method. The data is identified based on the type of image of women, namely in physical aspects, psychological, in the family, and in society. Data collection techniques using literature review with data analysis using informal techniques. The results showed that the novel contained images of Javanese women depicted by Mbok Warsi, Yu Rah, Bunda Tawangsri, and Bunda Masari consisting of images of Javanese women in physical having beautiful faces, attractive appearance, and inexpensive smile. In the psychological of being patient, loyal, always thinking positive, thorough and diligent, and accepting. In families simple, strong and unyielding character, th spirit provides motivation, clever, and obedient. In society, as Javanese women who are obedient to the prevailing traditions or customs, have courtesy, and are generous. Implicate the results of research in the novel in learning Indonesian in high school class XII on enjoying novels with basic competencies 3.9 analyzing the content and language in the novel.
\end{abstract}

Keywords:The image of Javanese Women, the Novel Garis Perempuan, the Implications of Language Learning.

\section{ABSTRAK}

Tujuan penelitian ini adalah untuk mendeskripsi citra perempuan Jawa yang terdapat dalam novel Garis Perempuan karya Sanie B. Kuncoro dan untuk mendeskripsi implikasi pembelajaran citra perempuan Jawa dalam novel Garis Perempuan terhadap pembelajaran bahasa Indonesia di SMA. Metode penelitian yang digunakan adalah metode deskriptif kualitatif. Sumber data berupa novel Garis Perempuan karya Sanie B. Kuncoro dengan wujud data berupa kata, frasa, klausa, dan kalimat. Wujud data diidentifikasi berdasarkan jenis citra perempuan. Teknik pengumpulan data menggunakan teknik kasian pustaka. Teknik analisis data menggunakan teknik informal. Hasil penelitian menunjukkan bahwa novel Garis Perempuan terdapat citra perempuan Jawa yang terdiri dari citra perempuan Jawa dalam aspek fisik yang digambarkan oleh tokoh Mbok Warsi, Yu Rah, Bunda Tawangsri, dan Bunda Masari memiliki wajah yang cantik, berpenampilan menarik, dan murah senyum. Dalam aspek psikis memiliki sifat sabar, setia, berpikir positif, teliti dan rajin, serta menerima. Dalam keluarga memiliki karakter sederhana, kuat dan pantang menyerah, semangat memberikan motivasi, pandai, serta penurut. Dalam masyarakatsebagai perempuan Jawa yang patuh terhadap tradisi yang berlaku, memiliki sopan satun, dan dermawan. Implikasi hasil penelitian dalam novel Garis Perempuandapat digunakan dalam pembelajaran bahasa Indonesia di SMA kelas XII pada materi menikmati novel kompetensi dasar 3.9 menganalisis isi dan kebahasaan dalam novel.

Kata Kunci: Citra Perempuan Jawa, Novel Garis Perempuan,Implikasi Pembelajaran Bahasa.

Cara sitasi:

Afidah, A. N.,Mulyono, T., Nirmala, A.A. (2020). Citra perempuan jawa dalam novel garis perempuan karya sanie b. Kuncoro dan implikasinya terhadap pembelajaran bahasa indonesia di sma. Jurnal wahana pendidikan, 7 (2), 113-122. 


\section{PENDAHULUAN}

Sugihastuti dan Suharto (2016:15) mengemukakan lima hal yang melatarbelakangi feminisme di Indonesia perlu diteliti. Pertama, kedudukan dan peran para tokoh perempuan dalam karya sastra Indonesia menunjukkan masih didominasi oleh laki-laki. Kedua, dari resepsi pembaca karya sastra Indonesia, secara sepintas terlihat bahwa para tokoh perempuan dalam karya sastra Indonesia tertinggal dari laki-laki. Ketiga, masih adanya resepsi pembaca karya sastra Indonesia yang menunjukkan bahwa hubungan antar laki-laki dan perempuan hanyalah merupakan hubungan yang didasarkan pada pertimbangan biologis dan sosial-ekonomis semata-mata. Keempat, penelitian sastra Indonesia telah melahirkan banyak perubahan analisis dan metodologinya. Kelima, banyak pembaca yang menganggap bahwa peran dan kedudukan perempuan lebih rendah dari lakilaki seperti nyata diresepsi dari karya sastra Indonesia. Dengan demikian, pandangan yang seperti ini layak ditilik kembali menggunakan penelitian sastra yang berperspektif feminis.

Di Indonesia, persoalan gender yang mengedepankan aspek feminisme salah satunya yang terdapat pada karya Sanie B. Kuncoro yaitu novel yang berjudul Garis Perempuan yang di dalamnya memuat citra perempaun Jawa yang sangat menarik untuk dikaji. Di mana pun perempuan memang menarik untuk dibahas (Sugihastuti dan Suharto, 2016:32). Citra perempuan khususnya perempuan Jawa dekat hubungannya dengan segudang tata krama yang mengikutinya. Pemikiran mengenai perempuan mestilah menjadi patuh, penurut, serta kalem sudah terpatri dalam kehidupan masyarakat di tanah Jawa termasuk pada karya sastra. Novel Garis Perempuan terdiri dari empat tokoh sentral yakni Gendhing, Ranting, Tawangsri, dan Zhang Mey. Keempat tokoh tersebut berlatar dari keluarga Jawa dan budaya patriarki yang menganggap virginitas sebagai hal yang suci dan sakral. Keempat tokoh sentral tersebut memiliki cara masing-masing dalam menghadapi permasalahan hidup yang dialami tidak lepas dari citra perempuan Jawa pendukung. Peran dari citra perempuan pendukung sangat berdampak berkenaan dengan pengambilan keputusan yang dilakukan oleh tokoh sentral dalam menghadapi permasalahan hidup. Penelitian ini akan meneliti citra perempuan Jawa yang meliputi citra diri perempuandan citra sosial perempuan. Berlandaskan beberapa paparan di atas, peneliti melakukan penelitian dengan judul Citra Perempuan Jawa dalam Novel Garis Perempuan Karya Sanie B. Kuncoro dan Implikasinya terhadap Pembelajaran Bahasa Indonesia di SMA. Penelitian ini akan terfokus pada citra perempuan Jawa (tokoh pendukung) antara lain tokoh Mbok Wasri, Yu Rah, Bunda Tawangsri, dan Bunda Masari.

Berdasarkan uraian yang telah dijelaskan pada latar belakang di atas, rumusan masalah dalam penelitian ini sebagai berikut. Bagaimana citra perempuan Jawa yang terdapat dalam novel Garis Perempuan karya Sanie B. Kuncoro dan Bagaimana implikasi pembelajaran citra perempuan Jawa dalam novel Garis Perempuan terhadap pembelajaran bahasa Indonesia di SMA. Sesuai dengan rumusan masalah yang ada, tujuan penelitiannya dirumuskan sebagai berikut. Untuk mendeskripsi citra perempuan Jawa yang terdapat dalam novel Garis Perempuan karya Sanie B. Kuncoro. Untuk mendeskripsi implikasi pembelajaran citra perempuan Jawa dalam novel Garis Perempuan terhadap pembelajaran bahasa Indonesia di SMA. Manfaat penelitian ini diharapkan dapat memperbanya kpandangan dan pemahaman yang mutakhir bagi pembaca tentang kajian citra perempuan Jawa. Selain itu, pengkajian novel Garis Prempuandapat berkontribusi pada kemajuan ilmu sastra Indonesia yakni menumbuhkan penghargaan berkenaan dengan analisis citra perempuan Jawa. Citra perempuan Jawa meliputi aspek fisik, psikis, dan citra sosial dalam konteks kajian keluarga dan masyarakat. Dengan penelitian ini, peneliti mampu mengetahui konkretisasi citra diri perempuan Jawa dalam novel Garis Perempuan.Bagi pembaca, diharapkan lebih menginterpretasikan citra perempuan Jawa yang dalam novel Garis Perempuan tentang arti dan prinsip kehidupan manusia khususnya perempuan Jawa.

Wicaksono (2017:68) menyatakan novel ialah bagian dari jenis prosa fiksi. Novel tergolong fiksi (fiction) karena hasil khayalan. Dapat disimpulkan novel ialah salah satu jenis karya sastra yang berwujud prosa fiksi yang menggambarkan kehidupan tokoh mulai dari konflik yang dihadapi dalam suatu alur atau suatu keadaan dengan panjangnya cukupan,membongkar perspektif kemanusiaan 
yang makin meluas dan disuguhkan dengan halus. Sugihastuti dan Suharto (2016:43) menyatakan karya sastra (novel) merupakan struktur yang bermakna. Novel tidak sekadar rangkaian tulisan yang menggairahkan ketika dibaca, tetapi merupakan struktur pikiran yang tersusun dari unsur-unsur yang padu. Untuk mengetahui makna-makna atau pikiran tersebut, karya sastra (novel) harus dianalisis.

Menurut Fakih (Sugihastuti dan Saptiawan, 2010:95), munculnya feminisme merupakan upaya perjuangan atas berbagai kontrol laki-laki. Salah satu persoalan pendorong lahirnya feminisme adalah ketidakadilan yang timbul dari perbedaan gender. Kritik sastra feminis berawal saat penolakan-penolakan perempuan menghadapi segregasi yang dialami dalam persoalan pendidikan dan sastra. Kritik feminis dalam sastra dinamakan kritik sastra feminis yang tidak lepas dari analisis gender. Kamla Bashin dan Nighat Said Khan (Nirmala, 2009:46), menyatakan feminisme tidak membantah perempuan mempunyai anak dan berkeluarga, tidak memandangfeminin sebagai satu-satunya kodrat perempuan, dan tidak menyetarakan makna kewanitaan serupa dengan IRT. Hakikatnya bahwa setiap perempuan perlu menentukan hal yang dikehendakinya.

Citra berarti paras, rekaan, gambaran tentang individu atau perorangan, perseroan, institut, maupun barang, dapat pula berarti kesan batin yang dimunculkan oleh sebuah kata, frasa, atau kalimat dan komponen dasar yang unik dalam prosa atau puisi dan merupakan konsep dasar konsep citra perempuan. Kemudian Danandjaja (Rejeki, 2013:21-22), menerangkan perempuan selalu dihubungkan dengan kesopanan, kelembutan, dan kecantikan. Sejalan dengan pendapat Danandjaja tersebut, Atmadja dan Satoto (Rejeki, 2013:21-22), menerangkan definisi wanita atau perempuan berakar dari wanodya kang puspita atau wanita yang ayu, anggun, molek, dan jelita. Hal tersebut menjad I lambang keelokan tiada tandingan. Menurut Indrawati (Sari, Syukur, dan Ino, 2018:33), masyarakat yang mempunyai pemisahan-pemisahan khusus dalam pertalian gender yang menujukkan peran dan posisi laki-laki lebih dominan dibanding perempuan merupakan penjelasan mengenai masyarakat Jawa. Menurut Fitriani, Qomariyah, dan Sumartini (2018:62) beranggapan perempuan Jawa dibawah kelasnya dari lelaki. Beberapa prinsip dasar yang dimiliki masyarakat Jawa mengenai perilaku batin yang benar, yakni anteng, kalem,dapat dikuasai, tenang, tidak gegabah,tabah, lembut, menghargai orang lain, bersahaja (sederhana), sadik, pasrah, dan tidak mementingkan diri sendiri. Pernyataan tersebut dikuatkan oleh Sukri dan Sofwan (Rejeki, 2013:2122), dilihat dari fisik dan psikis perempuan merupakan insan lemah daripada laki-laki. Itulah wujud wanita Jawa berdasarkan cara pandang budaya Jawa.

Menurut Setiawan (2018) ada istilah yang berkaitan erat dengan tata nilai kehidupan sehari-hari perempuan Jawa yakni gemi, nastiti, dan ngati-ati. Selain itu, ada pula istilah narima berarti menerima. Pendapat tersebut dikuatkan dalam Serat Centhini (Suryadi, 2018:445) yang menyatakan bahwa perempuan Jawa mempunyai karakter selalu berhati-hati, rajin, dan terampil. Selanjutnya Endraswara (2016) berpendapat bahwa orang Jawa memiliki prinsip hidup yang tercermin dalam ungkapan, "urip iku urup". Artinya, hidup itu menyala. 'nyala' membawa terang yang dapat memperlihatkan kepada kita bahwasanya dunia ini penuh keindahan. Berpikir positif ibarat 'nyala' itu, yang mampu memerangi kegelapan atau pikiran negatif dan membawa sinar terang bagi diri kita dan lingkungan sekitar. Menurut Suseno (Ariani, 2016:288) perempuan Jawa adalah perempuan yang dalam kehidupan sehari-hari mengikuti adat istiadat dan kebudayaan Jawa. Kehidupan perempuan di Indonesia khususnya Jawa banyak dipengaruhi oleh budaya yang memang sudah melekat dalam kehidupannya, khususnya budaya wayang. Salah satunya adalah tentang perempuan Jawa yang belajar untuk menjadi perempuan yang baik melalui sosok dan figur dalam lakon-lakon pergelaran wayang kulit. Pendapat di atas dikuatkan oleh Darweni (Ariani, 2016:288) dalam adat Jawa, seorang istri yang ideal harus memiliki sikap seperti yang dikisahkan dalam sosok Dewi Shinta yang harus berbakti kepada suami, rela menerima kondisi suami apa adanya dan rela ikut dalam kondisi yang tidak menyenangkan, sabar, setia sederhana, patuh, taat, dan terampil. Menurut Sewojo dan Stuers (Yuniarti, 2018:32) ada empat kelas perempuan Jawa 
yang digolongkan berdasarkan status sosial mereka di masyarakat yakni golongan miskin, golongan menengah, golongan santri, dan golongan priyayi.

Dari beberapa pendapat di atas dapat disimpulkan citra perempuan Jawa ialah bentuk gambaran mental spiritual dan perilaku keseharian yang diekspresikan oleh perempuan Jawa dalam segala aspek, yaitu fisik dan psikis serta keluarga dan masyarakat di mana perempuan Jawa mempunyai prinsip dasar mengenai sikap batin yang benar, yakni terkontrol, anteng, kalem, berkepala dingin, tidak gegabah, tabah, lembut, menghargai orang lain, bersahaja (sederhana), sadik, pasrah, dan tidak mementingkan diri sendiri (dermawan) serta kerap dianggap lebih rendah derajatnya dari lelaki. Citra perempuan dikelompokkan menjadi dua yakni citra diri perempuan dan citra sosial perempuan. Menurut Sugihastusi (Darwis dan Ismail: 2018), persoalan pokok yang mempelopori citra sosial perempuan ialah citra dirinya.

Menurut Repelita (2020:72) pendidikan merupakan sebuah proses yang tersusun dengan sistematik untuk mewariskan atau mentransmisikan budaya dari para pendidik kepada generasi penerus bangsa. Proses tersebut mengandung makna terhadap sebuah tindakan asasi yaitu pemilihan atau seleksi keterampilan, fakta nilai, sikap yang saling berharga dan penting untuk diwariskan kepada generasi penerus bangsa.

Salah satu pembelajaran bahasa Indonesia di SMA adalah pembelajaran sastra. Novel merupakan salah satu macam karya sastra yang diberikan dalam pembelajaran sastra di SMA. Oleh karena itu, dalam penelitian dapat diimplikasikan terhadap pembelajaran bahasa Indonesia di SMA kelas XII yaitu pada KD 3.9 menganalisis isi dan kebahasaan novel, yang memuat tentang unsur intrinsik dan ekstrinsik (menemukan isi).

\section{METODOLOGI PENELITIAN}

Menurut Ratna (2015:54), pendekatan didefinisikan sebagai cara-cara menghampiri objek. Sedangkan metode adalah cara-cara mengumpulkan, menganalisis, dan menyajikan data. Menurut Abrams (Sugihastuti dan Suharto, 2016:43), ada empat pendekatan dalam karya sastra, yaitu pendekatan mimetik, pendekatan pragmatik, pendekatan ekspresif, dan pendekatan objektif. Pada penelitian ini menggunakan pendekatan objektif. Menurut Abrams (Ratna, 2015:72), mengemukakan bahwa pendekatan objektif dibicarakan paling akhir dengan pertimbangan bahwa pendekatan ini justru merupakan pendekatan yang terpenting sekaligus memiliki kaitan yang paling erat dengan teori sastra modern, khususnya teori-teori yang menggunakan konsep dasar struktur. Penelitian ini menggunakan pendekatan objektif (teori strukturalisme) karena membahas citra perempuan Jawa dengan metode deskriptif kualitatif. Prosedur penelitian yaitu langkah-langkah yang dilakukan secara terencana dan sistmatis guna mendapatkan jawaban terhadap pertanyaan-pertanyaan tertentu. Prosedur atau langkah-langkah yang dilakukan harus sesuai dan saling mendukung satu sama lain, agar penelitian yang dilakukan mempunyai bobot dan tidak meragukan. Berikut langkah-langkah atau prosedur penelitian yang peneliti lakukan, yakni tahap persiapan atau perencanaan, pelaksanaan penelitian, dan tahap menuliskan hasil penelitian. Sumber data primer dan sekunderlah yang dipergunakan dalam penelitian. Sumber data yang memuat data pokok yakni data yang didapat secara langsung disebut dengan sumber data primer yang berasal dari data kepustakaan. Teks novel Garis Perempuan karya Sanie B. Kuncoro cetakan pertama yang dikeluarkan oleh penerbit Bentang pada bulan Januari 2010 dengan tebal 373 halaman menjadi sumber data primer dalam penelitian ini. Penelitian ini termasuk kualitatif. Oleh karena itu, wujud datanya berupa kata, kalimat, dan wacana yang menujukkan citra perempuan Jawa.

Berdasarkan sumber data dan wujud data yang telah peneliti tentukan, maka data yang ditemukan dalam novel tersebut diidentifikasi berdasarkan kajian feminisme (citra prempuan Jawa) dalam aspek fisik, psikis, dalam keluarga dan dalam masyarakat. Data yang telah terhimpun dikelompokkan terlebih dahulu sebelum dianalisis. Tahap setelah data digabungkan dengan teknik pustakamerupakan tahap pengelompokan data. Pengelompokan data ini meliputi hal-hal yang dihadapi oleh tokoh perempuan Jawa (pendukung) yaitu tokoh Mbok Warsi, Yu Rah, Bunda Masari, 
dan Bunda Tawangsri. Setelah itu memilah data dengan maksud untuk memfokuskan penelitian pada citra perempuan Jawa pada keempat tokoh tersebut. Cara menganalisis novel Garis Perempuan yang menjadi bahan dengan kritik sastra feminis dan analisis struktural adalah dengan fokus pada tokoh perempuan Jawa pendukung. Setelah itu, untuk memanifestasikan citra perempuan Jawa (pendukung) dalam novel Garis Perempuan yang meliputi citra perempuan Jawa diri sendiri (aspek fisik dan psikis) dan sosial (aspek keluarga dan masyarakat) dianalisis dengan memanfaatkan kritik sastra feminis. Kemudian ditarik kesimpulan dalam novel Garis Perempuan yang menunjukkan citra perempuan Jawa (pendukung). Penyajian hasil analisis dilakukan setelah data selesai dianalisis. Peneliti mepergunakan teknik penyajian hasil analisis berupa teknik informal.

\section{HASIL DAN PEMBAHASAN}

Hasil penelitian menunjukkan bahwa dalam novel Garis perempuan karya Sanie B. Kuncoro terdapat citra perempuan Jawa yang meliputi citra diri perempuan Jawa dalam aspek fisik, citra diri perempuan Jawa dalam aspek psikis, citra sosial perempuan Jawa dalam keluarga, dan citra sosial perempuan Jawa dalam masyarakat.

\section{Citra Perempuan Jawa dalam Aspek Fisik}

Citra diri perempuan dalam aspek fisik akan dilihat bagaimana fisik dari tokoh Mbok Wasri, Yu Rah, Bunda Tawangsri, dan Bunda Masari. Baik itu ciri fisik maupun penampilannya. Seperti yang diungkapkan oleh Atmadja dan Satoto (Rejeki, 2013:21-22) mengenai definisi wanita atau perempuan berakar dari wanodya kang puspita atau wanita yang ayu, anggun, molek, dan jelitamenjadilambang keelokan tiada tandingan. Adapun citra diri perempuan dalam aspek fisik yang terungkap dalam novel Garis Perempuan adalah Bunda Masari sebagai tokoh pendukung perempuan yang merupakan madu dari tokoh Ranting. Hal ini sebagaimana kutipan berikut.

Bunda Masari, demikian perempuan paruh baya itu dipanggil. Baik oleh para penghuni di seluruh antero rumah besar itu ataupun oleh para penduduk dikampung itu.

Perempuan itu selalu berkebaya panjang dengan warna yang selalu berpadu dengan kain jarit yang dikenakannya. Rambutnya tak selalu bergulung, kadang-kadang lebih sering dijalin kepang, yang menampakkan panjang rambut yang menggapai pinggang.

Seorang perempuan dengan pendar aura yang memancar tegas dan cantik meski tak tertutupi garis samar keriput wajah yang tak mampu menyembunyikan usia paruh baya yang dimilikinya. (Garis Perempuan, 2010:100).

Kutipan di atas menggambarkan kecantikan Bunda Masari yang nampak dari kerapian dalam penampilan, cara berpakaian, rambut, dan aura yang dimiliknya. Bunda Masari selalu mengenakan kebaya panjang yang merupakan pakaian khas perempuan Jawa dengan warna yang selalu berpadu dengan kain jarit yang dipakainya menunjukkan bahwa Bunda Masari selalu memerhatikan dalam setiap penampilannya meskipun sudah paruh baya. Hal ini karena Bunda Masari merupakan istri pertama dari Basudewo juragan tanah di kampungnya. Tidak heran jika Bunda Masari selalu menjaga penampilannya agar selalu menarik sehingga auranya terus memancar meskipun sudah paruh baya.

\section{Citra Diri Perempuan Jawa dalam Aspek Psikis}

Citra perempuan Jawa dalam aspek psikis yang terungkap dalam novel Garis perempuan karya Sanie B. Kuncoro digambarkan melalui sosok Mbok Wasri, Yu Rah, Bunda Tawangsri, dan Bunda Masira. Keempat tokoh tersebut memiliki psikologi yang sabar, setia, selalu berpikir positif, teliti dan rajin, serta menerima.

\section{Sabar}

Sabar adalah suatu kekuatan jiwa yang diwujudkan melalui sikap dan ketahanan untuk menderita sesuatu yang tidak diinginkan. Tingkat kesabaran antara laki-laki dan perempuan memang berbeda apalagi jika perempuan tersebut sudah berumah tangga. Hal itu sesuai dengan kutipan berikut. 
"Tapi, tumor sudah sebesar itu, apakah tidak berbahaya kalau tertunda oprasinya?" tanya Mbok Darmi menyiratkan cemas dalam tatap matanya (Garis Perempuan, 2010:37).

Suatu pagi.

Ranting baru saja selesai membantu simbok mandi dan berganti pakaian. Dengan kondisi perut sebesar itu, sementara badannya makin mengurus, bukan hal mudah bagi perempuan pesakitan melakukan sendiri aktivitas hariannya meski itu sekedar melangkahkan kaki. Maka, Ranting harus memapah setiap langkah dengan perlahan, membantu menyangga beban berat yang menggantung di perut Simbok. (Garis Perempuan, 2010:41)

Kutipan di atas menggambarkan Mbok Wasri memiliki jiwa yang sabar dalam menghadapi sakit tumor yang dideritanya yang semakin parah yang membatasi aktivitasnya sehingga harus dibantu Ranting dalam melakukan aktivitas hariannya. Sudah bertahun-tahun Mbok Wasri menderita karena sakit tumor, dia hanya mengandalkan tabungannya sembari menunggu uangnya terkumpul supaya cukup untuk biaya operasi.

Setia

Setia memiliki arti berpegang teguh (pada janji, pendirian, dan sebagainya), patuh, taat, tetap, dan teguh hati. Inilah kriteria yang mesti dimiliki perempuan Jawa. la menganggap suami bukan semata-mata menjadi suaminya ketika hidup di dunia, tetapi juga di akhirat kelak. Tercermin dalam ungkapan Jawa yang jelas menyebutkan kesetiaan sosok wanita terhadap suaminya adalah swarga nunut neraka katut (mengikuti ke surga maupun ke neraka). Perempuan Jawa selalu setia kepada pasangannya bagaimanapun kondisinya. Digambarkan secara jelas sikap setia perempuan Jawa melalui ungkapan: urip rekasa gelem, mukti uga bisa; sabaya mukti sabaya pati (hidup dalam kesusahan bersedia, hidup makmur pun bisa, sehidup semati dalam suka maupun duka). Hal itu sesuai dengan kutipan berikut.

"Bunda belum tidur?' tanyanya melihat Ibunya dari celah pintu.

"Menunggu ayahmu," jawab Bunda tanpa meninggalkan senyum.

"Tapi, sudah selarut ini."

"Tak apa. Lebih mudah menunggu ayahmu pada malam begini karena dia pasti pulang. Sementara menunggu dia bangun esok hari, lebih tidak jelas waktunya. Bisa pagi, tengah hari atau malah malam kembali," suara Bunda sangat biasa tanpa nada keluhan, nyaris datar. "Sementara Bunda harus melakukan sesuatu yang tak bisa tertunda pagi esok."

Tawangsri mengiakan. (Garis Perempuan, 2010:218-219)

"Jadi, Bunda berkorban demi aku?"

Bunda menggeleng, "Ini bukan pengorbanan, melainkan pilihan. Bukan pula semata dirimu. Tapi, juga demi rumah ini, keluarga ini, keberlangsungan usaha dagang yang tak mungkin kutinggalkan. Juga demi diriku sendiri, yang tak bisa melepaskan ayahmu."

"Mengapa Bunda tetap mencintai Ayah, setelah apa yang dia lakukan selama ini?" Bunda tersenyum.

"Kau terlalu muda untuk memahaminya," matanya bagai menerawangkan sesuatu, "Ayahmu itu tidak thukmis, itu yang utama. Tidak ada perempuan lain di hati ayahmu, selain kita berdua. Yakinilah itu. Karena itu, dia selalu pulang, seberapa pun terlambatnya. Tapi, Ayahmu juga tak mampu melepaskan diri dari klangenan 1tu, judi dan perbincangan malam dengan teman-temannya."

Seperti yang dilakukan Bunda. Demi kecintaan seorang ibu, maka tak ingin dihadapkannya anaknya pada pilihan-pilihan yang terbelah. Lalu, demi cintanya sebagai perempuan terhadap laki-laki pilihannya, maka dipasrahkannya diri pada keterikatan penuh kendala. Dan, demi dua orang yang dicintainya, maka disimpannya kotak pandora itu untuk dirinya sendiri, tak akan pernah dibukanya karena sudah diketahuinya apa yang akan terjadi sesudahnya (Garis Perempuan, 2010:226-228). 
Kutipan di atas menunjukkan betapa setianya Bunda Tawangsri terhadap suaminya. Bunda Tawangsri selalu menunggu suaminya pulang hingga pagi hari. Hal itu dilakukannya karena rasa cinta dan sayang terhadap suaminya. Bukan sekali dua kali tetapi bertahun-tahun ia lakukan tanpa rasa mengeluh sedikitpun.

\section{Selalu Berpikir Positif}

Orang Jawa memiliki prinsip hidup yang tercermin dalam ungkapan, Urip iku urup. Artinya, hidup itu menyala. "Nyala" membawa terang yang dapat memperlihatkan kepada kita bahwasanya dunia ini penuh keindahan. Berpikir positif ibarat "nyala" itu, yang mampu memerangi kegelapan atau pikiran negatif dan membawa sinar terang.

"Bunda, ingin kutanyakan sesuatu."

"Ya?"

Tawangsri menatap ke dalam mata Bunda.

"Apakah Bunda mencintai Ayah?"

"Tentu saja, kalau tidak, dari mana kau berasal?" jawab bunda segera. "Begitu indahnya dirimu, sejak bayi hingga saat ini, tentu karena paduan cinta yang sempurna." (Garis Perempuan, 2010:221)

"Yang terpenting adalah bahwa ayahmu selalu pulang setiap hari, jam berapa pun itu," sergah Bunda, bagai manghentikan keraguan Tawangsri. "Artinya, dia tetaplah milik kita. Tetap menjadi bagian dari keluarga ini, tetap sebagai ayahmu, suamiku, kepala rumah tangga." (Garis Perempuan, 2010:222)

"Perkawinan memunculkan banyak keterikatan yang tidak selalu bisa dipahami pihak lain, barangkali hanya terpahami secara individual. Perkawinan ini mengikatkan Bunda padamu, pada usaha keluarga dan juga cinta Bunda pada ayahmu."

"Mengapa aku menjadi kendala? Aku akan ikut ke mana Bunda pergi, dengan atau tanpa Ayah."

"Bunda tidak ingin menghadapkanmu pada sesuatu yang terbelah. Perpisahan, dengan cara sebaik apa pun dilakukannya akan melukai mereka yang terlibat di dalamnya, terutama dirimu sebagai korban. Akan mengondisikanmu untuk berada pada pilihan-pilihan yang bisa jadi memunculkan rasa bersalah setiap kali kau menentukan pilihanmu. Kau harus memilih $A$, artinya pada saat yang sama kau harus melepaskan $B$, sementara hatimu tidak menghendakinya. Begitupun ketika kau memilih yang sebaliknya. Lalu, kebahagiaan apa yang Bunda cari bila harus menghadapkanmu pada hal-hal serupa itu?" (Garis Perempuan, 2010:226).

Kutipan di atas menunjukkan bahwa Bunda Tawangsri selalu berpikir positif terhadap suaminya meskipun perlakuan yang Bunda Tawangsri terima tidak selalu positif. la mencoba meyakinkan anaknya untuk tidak berburuk sangka. Bahwa ayahnya akan pulang jam berapapun itu akan selalu ditunggu. la juga tidak ingin anaknya dihadapkan dengan pilihan yang akan menyulitkan. Sehingga Bunda Tawangsri lebih memilih utuk selalu berpikir positif dan yakin terhadap pilihan yang telah dipilinnya.

\section{Teliti dan Rajin}

Dalam Jawa ada istilah nastiti. Nastiti memiliki arti cermat dan teliti, dan ngati-ati berarti mempunyai sikap hati-hati. Ada pula istilah Titi bermakna teliti, jeli, dan cermat. Ketelitian sesungguhnya sangat diperlukan dalam segala aktivitas atau kegiatan. Seseorang yang bersikap teliti, jeli, dan cermat dalam mengelola rumah tangganya akan berpengaruh terhadap kedamaian dan ketenteraman dalam rumah tangga. Hal tersebut sesuai dengan gambaran perempuan Jawa pada kutipan berikut.

"Hati-hati meremas baju putih itu," Ibu memperingatkan. "Itu rok Cik Ming, bahannya renda halus, kalau terlalu keras kau peras bisa sobek." 
Begitulah, terhadap baju-baju yang indah dan halus itu, Gendhing hanya berkenan menyentuhnya ketika membantu ibunya. Ibunya dalah buruh cuci yang bertugas mencuci baju-baju kotor dari beberapa pelanggannya. Cik Ming adalah salah satu dari pelanggan itu. (Garis Perempuan, 2010:16)

Kutipan di atas menggambarkan betapa telitinya Yu Rah dalam setiap pekerjaan yang ia lakukan. Yu Rah berprofesi sebagai buruh cuci di kampungnya. Pada kutipan tersebut terlihat memperingati Gendhing supaya hati-hati dalam meremas baju putih milik Cik Ming, pelanggannya. Selain Yu Rah.

\section{Menerima}

Dalam Jawa ada istilah narima berarti menerima. Arti makan kata narima lebih dalam ialah menerima dengan bersyukur, ikhlas, dan telah merasa puas. Oleh karena itu perempuan Jawa menerima dengan ikhlas apa pun pemberian suaminya. Hal ini sesuai dengan kutipan berikut.

"Bukan hal yang mudah berada diposisiku, menerima Renjani, dirimu, lalu entah siapa lagi sesudah ini walau sekarang relatif lebih mudah. Yang tersulit adalah saat maru pertama, menyadari bahwa milikmu yang utuh harus dibagi. Tapi, untuk terbagi, mau dibagi tiga, lima atau sepuluh, podo wae [sama saja]. Yang terutama sekarang , bagaimana menerima pembagian itu dengan akur, tanpa perlu saling bersaing atau melukai." (Garis Perempuan, 2010:102)

"Ada beberapa kondisi yang menghadapkan kita sebagai perempuan dengan perempuan lainnya dalam situasi permusuhan. Permaduan seperti ini lebih sering diterjemahakan sebagai persaingan. Pada beberapa tradisi hal ini sah dilakukan dengan dalih agama atau hukum alam sebagai pembenaran. Dan, kita terutama para perempuan dengan keterbatasan kemampuan finansial, harus menerima tanpa pilihan. Maka akan lebih parah bila kita menyikapinya dengan perebutan dan persaingan. Paham maksudku?"

Bunda Masari mengantarkannya hingga pintu pendopo, lalu disentuhkannya kedua pipinya pada pipi Ranting sebagai salam. Alangkah menyentuhnya salam itu, setidaknya bagi Ranting, seakan-akan sebuah isyarat dia telah diterima sebagai bagian dalam keluarga besar itu. Semoga bukan sebagai duri, Ranting berharap, melainkan sebagai kembang yang baru tumbuh dan melengkapi deretan tanaman pada sebuah taman. (Garis Perempuan, 2010:103).

Kutipan di atas menggambarkan betapa Bunda Masari sangat menerima apapun keputusan suami, bahkan keputusan untuk dimadu dan menerima madunya dengan sangat baik. la hanya berpikir bagaimana menerima pembagian itu dengan akur, tanpa perlu saling bersaing atau melukai. la mengatakan perempuan dengan keterbatasan kemampuan finansial, harus menerima tanpa pilihan.

\section{Citra Sosial Perempuan Jawa dalam Keluarga Sederhana}

Perempuan Jawa juga merupakan individu yang sangat sederhana. Mereka terbuka untuk orang-orang khas yang menatap kemewahan, bagi mereka pakaian, makanan, dan tempat tinggal yang cukup. Misalnya kesederhanaan yang diajarkan kepada sang anak. Hal ini sesuai dengan kutipan berikut.

Ranting memegang erat-erat bakul kereweng-nya, seakan-akan menjaga dengan sungguh-sungguh keping-keping uangnya. Seakan-akan keeping-eping kereweng itu adalah lembar uang yang sesungguhnya. Seakan-akan menggenggam erat impiannya supaya tak terlepas imajinasi itu darinya karena sungguh tak dimilikinya keping harta itu di dunia nyata. Di dunia nyata di rumah berlantai tanah tempat dia tinggal, dengan dinding anyaman bambu di empat sisinya, tak tersimpan sekeping harta pun. Yang tersedia hanyalah keeping-keping karak, kerupuk beras buatan ibunya, yang bila terjual menghasilkan lembar uang yang tak seberapa, yang hanya cukup untuk membeli bahan baku pembuatan karak selanjutnya dan menyisakan sebakul nasi beserta lauk sangat sederhana untuk mengisi perut seisi rumah. 
Hanya itu. Ibunya bahkan tak pernah memiliki dompet karena tak akan ada lembar uang yang sempat singgah di dalamnya (Garis Perempuan, 2010:9)

"Yo wis ndak apa-apa, nanti kita makan sendiri. Karak melempem enak dimakan dengan nasi putih hangat. Dulu ayahmu suka makan itu, ditambah dengan sambal kecap atau sambal bawang." (Garis Perempuan, 2010:57)

Kutipan di atas menggambarkan betapa perempuan Jawa sangat sederhana dalam kehidupannya. Sosok Mbok Wasri menggambarkan kesederhanaan dari tempat tinggal dan makanan yang dimakan. Keadaan rumah yang sangat sederhana, yang tersedia hanyalah keepingkeping karak, kerupuk beras buatan Mbok Wasri, yang bila terjual menghasilkan lembar uang yang tak seberapa, yang hanya cukup untuk membeli bahan baku pembuatan karak selanjutnya dan menyisakan sebakul nasi beserta lauk sangat sederhana untuk mengisi perut seisi rumah. Bahkan tak Jarang Mbok Wasri dan keluarga hanya makan dengan lauk karak melempem dengan nasi putih hangat.

\section{Kuat dan pantang menyerah}

Karakter ini bisa terilhat jelas di pedesaan Jawa, perempuan Jawa bekerja membantu kehidupan keluarga di sawah, rumah sendiri atau rumah orang lain. Sifat dasar mereka adalah tangguh, pekerja keras dan pantang menyerah dalam menghadapi apapun. Hal ini sesuai dengan kutipan berikut.

"Ran, Simbok akan bertahan dan kuat sampai kapan pun karena hanya itu yang kumiliki, kekuatan dan kemampuan untuk bertahan. Tapi, harus kukatakan kepadamu bahwa tawaran Basudewo bukan guyonan. Dia serius!" seru Simbok dengan sungguh, berusaha meyakinkan Ranting. (Garis Perempuan, 2010:65)

Simbok tidak pernah memberikan janji, untuk hal apa pun juga. Ketika Ranting kecil menginginkan sesuatu selalu diutarakan tanpa paksaan, Simbok selalu hanya menerima permintaan itu, lalu menyimpannya lebih sebagai harapan dalam diam. Diam yang ternyata menyimpan usaha. Hingga suatu saat kemudian secara tak terduga memberikan wujudnya kepada Ranting (Garis Perempuan, 2010:67).

Kutipan di atas menggambarkan Mbok Wasri adalah seorang ibu atau perempuan Jawa yang kuat dan pantang menyerah. Kuat dan bertahan dengan keadaan yang pesakitan dan tetap bekerja membuat kerak untuk mencukupi kebutuhan sehari-hari. Selain kuat, Mbok Wasri juga perempuan Jawa yang pantang menyerah. Apapun akan diusahakan hingga keinginan sang anak terwujud.

\section{Semangat Memberikan Motivasi}

Perempuan Jawa dalam keluarga salah satunya berperan sebagai lbu yang selalu semangat memberikan motivasi untuk anak-anaknya. Peran seorang ibu sangatlah penting untuk anak menjalankan kehidupan yang baik sekaligus bermakna. Dalam menjalankan itu semua perlu adanya proses pendidikan yang baik. Ibu menginginkan yang terbaik untuk anaknya, bahkan apapun akan dilakukan demi kebaikan sang anak. Hal tersebut sesuai dengan kutipan berikut.

"Memang kau harus bekerja, tapi tidak dengan mencuci baju," sergan Ibu. "Kalau aku menjadi babu cuci, kujalani dengan ikhlas karena aku bodoh, sekolah nunggak berkalikai. Tapi, kau ini pintar. Tidak selayaknya kauwarisi profesi babu cuci ini dariku. Amit-amit jabang bayi!" (Garis Perempuan, 2010:133).

Gendhing tercenung. Sikap penolakan orangtuanya terhadap alternatifnya yang tercetus dengan iseng jelas mengisyaratkan nada kemarahan. Sekaligus terbaca dengan jelas betapa sesungguhnya penolakan itu terjadi karena hasrat yang besar dari orangtua untuk melindungi anaknya. Semangat untuk memberikan yang terbaik pada sang anak dan tidak membiarkan keburukan atau kerendahan yang terjadi pada mereka, terwariskan.(Garis Perempuan, 2010:133-134).

Kutipan di atas menggambarkan peran Yu Rah sebagai ibu dalam keluarga yang menginginkan hal baik untuk Gendhing. Termasuk dalam hal pendidikan dan pekerjaan. Yu Rah 
menginginkan Gendhing mendapatkan pekerjaan yang layak, bukan seperti Yu Rah yang hanya seorang buruh cuci. Yu Rah Semangat untuk memberikan yang terbaik pada sang anak dan tidak membiarkan keburukan atau kerendahan yang terjadi pada Yu Rah, terwariskan.

Pandai

Pandai dalam hal apa saja yang dibutuhkan perempuan, misalnya pandai dalam pembawaan diri dan pandai dalam menyelesaikan setiap permasalahan. Perempuan yang pandai tidak akan kehabisan cara untuk mengatasi berbagai masalah kehidupan yang akan menerjang nantinya. Hal ini sesuai dengan kutipan berikut.

"Ibumu sehat?" Tanya Bunda Masari dengan nada yang sangat biasa.

Penguasaan diri yang sungguh tidak dimiliki banyak perempuan. Seakan-akan Ranting adalah seorang yang biasa untuknya dan bukan "madu" baginya.

"Sampun sehat Bunda, matur nuwun [sudah sehat, terima kasih]." Jawab Ranting santun.

"Anggap aku Mbakyumu, sekalipun aku lebih pantas jadi ibumu."

"Ya, Bunda."

"Kita telah menjadi bagian dari sebuah keluarga. Mungkin akan diperlukan banyak toleransi untuk menjalaninya. Ini ibarat sebuah jalan raya, selama masing-masing berjalan sesuai jalurnya, pasti segala sesuatu berlangsung dengan baik. Tidak perlu terjadi tabrakan kalau kita tidak saling berebut jalan atau merasa jalan itu milik kita sendiri dan merasa sebagai pemilik tunggal jalan itu." (Garis Perempuan, 2010:101)

Kutipan di atas menggambarkan sosok Bunda Masari yang pandai dalam penguasaan dan pembawaan diri sehingga dapat dihadapi masalah tersebut dengan pemikiran yang jernih dan tenang.

Penurut

Perempuan Jawa juga menjunjung tinggi lelaki sebagai imam atau pemimpinnya. Hal ini membuat wanita Jawa cenderung penurut dan tidak suka membantah. Apa yang dikatakan pasangan akan mereka turuti, selama hal itu dianggap baik. Hal ini sesuai dengan kutipan berikut.

"Perkawinan tidak terkonfigurasi seperti tim orkestra, tempat setiap pemusik akan memainkan alat musik bagiannya sesuai arahan konduktor dan mengolah nada sesuai partitur yang ada di depannya."

Bunda menatapnya sungguh-sungguh.

"Dalam perkawinan, betapapun partitur itu ada dan terwujud sebagai etika perkawinan yang bahkan dilindungi undang-undang perkawinan dan kaidah agama, masingmasing pelakunya sering kali memainkan nada pilihannya sendiri dan bahkan membuat aturan sendiri yang dianggapnya bisa diberlakukan pada 'kerajaan' kecilnya."

"Mengapa Bunda bertahan? Apa artinya mempertahankan semua ini?"

"Bagaimanapun Ayahmu adalah konduktor dan Bunda berusaha memainkan nada sesuai partitur yang dikehendakinya, selama Bunda mampu menjalaninya. Tapi, bahwa Bunda mungkin bisa membuat dan memainkan partiturku sendiri adalah suatu hal yang mungkin terjadi ketika kondisi tak terelakkan." (Garis Perempuan, 2010:225)

Kutipan di atas menunjukkan bahwa Bunda Tawangsri adalah perempuan Jawa yang penurut. Bunda Tawangsri menganggap suaminya adalah konduktor di mana Bunda Tawangsri akan selalu menurut dengan suami selama dia mampu menjalaninya.

Citra Sosial Perempuan Jawa dalam Masyarakat

Citra sosial perempuan erat kaitannya dengan norma dan sistem nilai yang berlaku dalam satu kelompok masyarakat, tempat perempuan menjadi anggota dan berhasrat mengadakan hubungan antarmanusia. Adapun citra sosial perempuan Jawa yang terdapat dalam novel Garis Perempuan karya Sanie B. Kuncoro digambarkan bahwa sosok Mbok Wasri dan Bunda Masari merupakan perempuan Jawa yang patuh terhadap tradisi atau adat istiadat yang berlaku, memiliki sopan satun, dan dermawan atau suka memberi. 


\section{Patuh terhadap Tradisi yang Berlaku}

Perempuan Jawa sudah terbiasa diajari nilai-nilai adat dan budaya yang berlaku dari nenek moyang mereka. Hal ini membuat perempuan Jawa tumbuh menjadi perempuan yang memegang teguh ajaran adat istiadat yang terpelihara secara turun-temurun itu. Hal ini sesuai dengan kutipan berikut.

"Bancaan-bancaan... ayo kalian kemari...."

"Ya, sekarang Ajeng sudah perawan. Jadi dibancaki untuk syukuran," Bulik Kasni yang mendengar obrolan anak-anak itu menjelaskan. "Nanti suatu saat kalian juga akan dibancaki kalau saatnya tiba ketika kalian menjadi perawan." (Garis Perempuan, 2010:1112)

"Artinya kau bukan anak-anak lagi," kata Simbok kemudian, "tapi, telah menjadi perempuan muda. Siap dilamar, lalu kawin, punya anak."

"Yo, ngono kui [ya, begtulah]." Simbok mengiakan. "Semua perempuan akan seperti itu. Wis dalane wong wedok [Sudah jalannya orang perempuan]. Mengapa menanyakan hal itu?" (Garis Perempuan, 2010:13)

"Kau nanti ingin dibancaki juga?" Tanya Simbok dengan suara nada mengambang, menyimpan keraguan. Keraguan yang muncul karena tahu bahwa pertanyaan itu sesungguhnya tak perlu diungkapkan. Realita jawaban sudah tersedia sejak awal bahwa dia tidak akan sanggup mewujudkannya. (Garis Perempuan, 2010:14)

"Yo wis," Simbok mengusap peluh di dahi dengan punggung tangan, menyisakan bercak abu kehitaman di dahinya. "Biyen, Simbok juga tidak bancaan. Ora opo-opo [tidak apa-apa]. Nyatane, aku tetap perawan ketika menikah dengan bapakmu.

"Keperawanan ora tergantung bancaan. Dengan atau tanpa bancaan semua peremuan tetaplah perawan. Dibancaki puluhan tampah pun, kalau tidak bisa menjaga keperawanannya dengan baik, ya percuma. Nasi bancaan, seberapa kekuatannya? Lha wong cuma sega [itu sekadar nasi]. Zaman sudah sesulit ini, tidak bisa diadang atau diatasi segala kegilaan zaman itu cuma dengan nasi bancaan."

"Ya Mbok." Ranting mengangguk.

"Wis, ora usah dikipasi [sudah, tidak perlu dikipasi]. Nanti kebesaran api, nasinya bisa hangus, mandilah lalu belajar dan mengerjakan tugas sekolahmu. Kalau sudah selesai, bantu lagi menata karak untuk dijemur." (Garis Perempuan, 2010:115)

Kutipan di atas menggambarkan sosok Mbok Wasri Sesungguhnya Mbok Wasri adalah Perempuan Jawa yang patuh terhadap adat-istiadat yang berlaku, hanya saja Mbok Wasri mempunyai keterbatasan ekonomi yang menyebabkan tidak terpenuhinya tradisi Bancaan untuk sang anak.Dijelaskan bahwa anak perempuan ketika sudah perawan, sebagai rasa syukur maka pihak keluarga mengadakan acara bancaan. Acara syukuran tersebut berupa pembagian nasi bancaan kepada tetangga-tetangga.

\section{Sopan santun}

Perempuan Jawa juga terkenal dengan cara mereka yang sangat sopan. Sapaannya juga sangat lembut dan sangat ramah. Perempuan Jawa benar-benar merawat karma atau toto kromo dalam interaksi sehari-hari mereka. Perempuan Jawa dikenal ramah dan kalem serta santun. Dalam berbicara perempuan Jawa sangat lemah lembut. Hal ini dilakukan agar lawan bicara tidak tersinggung. Kesopanan tersebut tergambar dari cara bicara dan tutur kata. Hal ini sesuai dengan kutipan berikut.

Simbok terperangah, atau barangkali takjub adalah kata yang lebih tepat. Sosok Basudewo yang tinggi tegap berdiri diambang pintu rumah, memunculkan ketakjuban perempuan paruh baya itu dengan tingkat keterkejutan yang sangat tinggi. Membuat seluruh tubuhnya kaku, bergeming di tepi ambennya tanpa mampu mengucap sepatah kata pun meski itu untuk membalas salam kedatangan Basudewo. 
"Nuwun sewu, Den [Maaf, Tuan], tidak bisa menyambut kedatangan tamu dengan layak, beginilah keadaan saya," kata Simbok terbata, masih dengan antara rasa percaya dan tidak yang mengambang melihat kedatangan Basudewo dirumahnya. (Garis Perempuan, 2010:59)

Kutipan di atas menggambarkan betapa sopannya sosok Mbok Wasri dengan segala keterbatasan yang dimilki ia tetap menyambut tamunya dengan baik. Yang sedang dihadapi Mbok Wasri adalah juragan tanah yang sangat terkenal di kampungnya. Mbok Wasri tetap menunjukkan kesopanan melalui kata-kata saat berbicara meskipun lawan bicaranya lebih muda.

\section{Dermawan atau Suka Memberi}

Memberikan sesuatu kepada orang lain yang membutuhkan merupakan tindakan yang mulia. Saat melihat orang yang membutuhkan, kita diwajibkan untuk membantu meringankan beban yang membutuhkan, hal ini merupakan bagian dari tenggang rasa dan perempuan Jawa dalam novel Garis perempuan mempunyai karakteristik tersebut. Hal ini sesuai dengan kutipan berikut.

"Lipat daster-daster itu, Sri." Bunda menunjuk setumpuk daster batik aneka warna.

"Tidak usah pakai plastik, tumpuk saja satu kodi, 20 daster, terus diikat rafia."

"Kalau tersisa, buat saya, ya, Bunda?" pinta Tawangsri setengah merajuk.

"Tidak mungkin ada sisa, jumlahnya wis pas 100 daster untuk 5 kodi. Lagi pula itu bukan daster kecil, akan kebesaran kalau kau pakai. Tur, dastermu wis akeh tho [lagi pula bukankah dastermu sudah banyak?]"

"Sanes kangge kulo, meniko kagem [bukan untukku, melainkan untuk] Gendhing dan Ranting, dastere wis sowek-sowek [daster mereka sudah sobek-sobek].

"Ngono tho? Yo wis, besok kuambilkan dari pasar wae, ada beberapa sisa dagangan yang bisa mereka pakai."

"Sungguh, Bunda?"

Bunda mengangguk, menyimpan senyum (Garis Perempuan, 2010:23)

Dan, berakhirlah mereka sebagai dagangan sisa dan menjalani takdirnya menemukan pemiliknya tidak memalui jalur pembelian, tetapi sebagai barang pemberian. Seperti daster-daster yang kemudian dibawa Bunda dari pasar untuk diberikan kepada Gendhing dan Ranting, menggantikan daster using dan pudar yang selalu dipakai kedua perempuan kecil itu (Garis Perempuan, 2010:27).

Pada kutipan di atas digambarkan perempuan Jawa yaitu sosok Bunda Tawangsri memiliki sifat yang suka memberi atau dermawan. Bunda Tawangsri selalu menyisihkan sebagian dagangannya yang berupa daster untuk diberikan kepada teman Tawangsri yaitu Ranting dan Gendhing yang berasal dari keluarga kurang mampu.

\section{Implikasi Hasil Penelitian terhadap Pembelajaran di SMA}

Hasil penelitian ini memiliki keterkaitan dengan pembelajaran bahasa Indonesia di SMA. Salah satu pembelajaran bahasa Indonesia adalah berkaitan dengan pembelajaran sastra. Pembelajaran bahasa Indonesia tentang sastra di SMA belum sepenuhnya maksimal karena manfaat yang ada di dalam karya sastra belum sepenuhnya tersampaikan kepada peserta didik. Penyebab pembelajaran sastra dirasa monoton karena kurangnya inovasi dan kreativitas dalam pembelajaran. Salah satu contoh inovasi dalam pembelajaran sastra adalah guru berani memberikan jenis novel yang menarik dengan catatan novel tersebut mudah dipahami oleh peserta didik dan tetap memperhatikan nilainilai yang terkandung di dalamnya. Jika pembelajaran sastra di SMA sepenuhnya sudah tersampaikan maka akan memperoleh manfaat. Suharianto (2009:107) menyatakan bahwa keuntungan yang bisa didapat dari pembelajaran satra di SMA antara lain dapat meningkatkan keterampilan berbahasa (menyimak, membaca, berbicara, dan menulis), memeperluas wawasan tentang manusia dan kehidupannya, memebantu pembentukan watak, dan mampu mengembangkan diri pribadi.

Citra perempuan Jawa dalam novel Garis Perempuan dapat menambah wawasan berdasarkan pada pemahaman nilai citra perempuan Jawa yang terkandung khususnya tentang kesetiaan, rasa 
sabar, rajin dan teliti, pantang menyerah, semangat memberikan motivasi, menerima, selalu berpikir positif, suka memberi patuh terhadap budaya yang berlaku, serta memiliki sopan santun yang tinggi. Novel ini bermanfaat untuk menunjang pembelajaran sastra di SMA. Pembelajaran bahasa Indonesia berkaitan dengan sastra pada novel di SMA terdapat pada buku bahasa Indonesia semester ganjil kelas XII yang diterbitkan oleh Kementrian Pendidikan dan Kebudayaan Republik Indonesia tahun 2018 pada halaman 110 tentang menikmati novel dengan kompetensi dasar 3.9. menganalisis isi dan kebahasaan dalam novel dengan indikator menentukan isi (unsur intrinsik dan unsur ekstrinsik) dan kebahasaan (ungkapan, majas, peribahasa). Pada penelitian ini penulis hanya fokus pada unsur ekstrinsik yaitu tentang citra perempuan Jawa.

\section{SIMPULAN}

Berdasarkan hasil penelitian dan pembahasan yang telah diuraikan di atas, disimpulkan bahwa citra perempuan Jawa dalam novel Garis Perempuan sebagai berikut. Dalam novel Garis Perempuan terdapat citra perempuan Jawa yang digambarkan oleh tokoh Mbok Warsi, Yu Rah, Bunda Tawangsri, dan Bunda Masari terdiri dari citra perempuan Jawa dalam aspek fisik memiliki wajah yang cantik, berpenampilan menarik, dan murah senyum. Dalam aspek psikis yang memiliki sifat sabar, setia, selalu berpikir positif, teliti dan rajin, serta menerima. Dalam keluarga yang memiliki karakter sederhana, kuat dan pantang menyerah, semangat memberikan motivasi, pandai, serta penurut. Dalam masyarakat, sebagai perempuan Jawa yang patuh terhadap tradisi atau adat istiadat yang berlaku, memiliki sopan satun, dan dermawan. Implikasikan hasil penelitian dalam novel Garis Perempuan karya Sanie B. Kuncoro dapat digunakan dalam pembelajaran bahasa Indonesia di SMA kelas XII pada materi menikmati novel dengan kompetensi dasar 3.9 menganalisis isi dan kebahasaan dalam novel.

Berdasarkan simpulan di atas, penulis menyampaikan beberapa saran yang perlu diketahui, semoga bermanfaat bagi pihak yang terkait sehingga dapat memajukan dunia pendidikan khususnya sastra. Bagi guru dalam memilih materi pembelajaran khususnya pada novel diharapkan memilih jenis novel menarik yang menggunakan bahasa yang mudah dipahami peserta didik sehingga dapat menambah pengetahuan akan karya sastra dan tetap memperhatikan nilai-nilai positif di dalamnya salah satu novel yang cocok digunakan adalah novel Garis Perempuan Karya Sanie B. Kuncoro. Bagi Peneliti Sastra seharusnya dapat menyaring karya sastra yang sedang dibacanya karena karya sastra yang baik itu dapat diterapkan dalam kehidupan sehari-hari. Bagi Pembaca dalam memanfaatkan novel Garis Perempuan, hendaknya pembaca mengambil sisi positif dari sosok perempuan Jawa dalam novel tersebut.

\section{REKOMENDASI}

Penelitian tentang citra perempuan Jawa pada novel ini hanya sebagian kecil dari penelitian sastra, peneliti selanjutnya dapat mengkaji dengan pendekatan yang lainnya. Penggunaan novel dengan tema yang menarik dalam penelitian juga dapat digunakan untuk memperkaya pengetahuan tentang karya sastra. Dalam memanfaatkan novel hendaknya pembaca mengambil sisi positif dari tokoh dalam novel karena memiliki pesan-pesan kehidupan yang mendidik sebagai pelajaran dalam kehidupan sehari-hari.

\section{UCAPAN TERIMA KASIH}

Terima kasih kepada Fakultas Keguruan dan IImu Pendidikan Universitas Galuh Ciamis, yang telah membantu penulis dalam publikasi artikel ini dan terima kasih juga untuk pihak-pihak yang telah membantu dalam pelaksaan penelitian. 


\section{DAFTAR PUSTAKA}

Ariani, Iva. (2016). "Feminisme dalam Pergelaran Wayang Kulit Purwa Tokoh Dewi Shinta, Dewi Kunti, Dewi Srikandi". Jurnal Filsafat Universitas Gajah Mada. Online. https://jurnal.ugm.ac.id. 26 (2), 278-284. Diunduh pada 7 Juli 2020.

Darwis, Anugrah, Taufik Ismail. 2018. "Citra Perempuan dalam Iklan Sabun Media Elektronik (Kajian Feminisme)". Seminar Nasional Universitas Makassar. Online. http://eprints.unm.ac.id/id/eprint/11285. Diunduh pada 9 Januari 2020.

Endraswara, Suwardi. 2016. Berpikir Posistif Orang Jawa. Yogyakarta: Pustaka Narasi.

Fitria, Nur, U'um Qomariyah, dan Sumartini. 2018. "Citra Perempuan Jawa dalam Novel Hati Sinden Karya Dwi Wahyuningsih: Kajian Feminisme Liberal”. Jurnal sastra Indonesia. 7 (1), 62-72. Online. http://journal.unnes.ac.id/sju/index.php/isi/article/view/2918. Kuncoro, Sanie B. 2010. "Garis Perempuan". Yogyakarta: Penerbit Bentang.

Nirmala, Afsun Aulia. 2009. "Naskah Drama Sampek Engtay Karya N. Riantiarno dan Romeo Juliet Karya William Shakespere". Tesis Universitas Negeri Surakarta. Online. http://id.scribd.com/doc/306040134/afsun-838.

Ratna, Nyoman Kutha. 2015. Teori, Metode, dan Teknik Penelitian Sastra. Yogyakarta: Pustaka Pelajar.

Repelita, Tridays. 2020. "Efektifitas Hasil Belajar Siswa pada Pelajaran Bahasa Indonesia dengan Memanfaatkan Metode Pembelajaran Drill (Latihan)". Jurnal Wahana Pendidikan. 7 (1), 71-76. Online. https://jurnal.unigal.ac.id/index.php/jwp/article/view/3240/2899.

Sari, Desi Ratna, La Ode syukur, dan La Ino. 2018. "Citra Perempuan Jawa dalam Novel Pengakuan Pariyem: Dunia Batin Seorang Wanita Jawa Karya Linus Suryadi Ag.". Cakrawala Listra. 1 (1), 31 42. Online. http://journal.fib.uho.ac.id/index.php/cakrawalalistra/article/view/347.

Setiawan, Agus. 2018. "Perempuan Jawa Sarat Nilai-Nilai Budaya Jawa". Online. https://tazkiaiibs.sch.id/blog/Agussetiawan/post/perempuan-jawa-sarat-nilai-nilai-budaya-jawa. Diunduh pada 14 Juli 2020.

Sugihastuti, Itsna Hadi Saptiawan. 2010. Gender \& Infeoritas Perempuan. Yogyakarta: Pustaka Pelajar.

Sugihastuti, Suharto. 2016. Kritik Sastra Feminis. Yogyakarta: Pustaka Pelajar.

Suharianto, S. 2009. Menuju Pembelajaran Sastra yang Apresiatif. Semarang: Bandungan Institute.

Suryadi, M. 2018. "Karakter Perempuan Jawa dalam Leksikon Jawa". NUSA. 13 (3), 445. Online. https://ejournal.undip.ac.id/index.hp/nusa/article/view/20583/13970.

Wicaksono, Andri. 2017. Pengkajian Prosa Fiksi. Yogyakarta: Penerbit Garudhawaca.

Yuniarti, Eka Sulis. 2018. "Pendidikan bagi Perempuan Jawa pada Abad ke 19". Sejarah dan Budaya. 12 (1), 30-38. Online. http://journal2.um.ac.id/index.php/sejarah-dan-budaya/article/download/4117/2258. 